\title{
Reducing greenhouse gas emissions through genetic selection in the Australian dairy industry
}

\author{
C. M. Richardson, ${ }^{1,2} \odot$ P. R. Amer, ${ }^{3} \odot$ C. Quinton, ${ }^{3} \odot$ J. Crowley, ${ }^{3}$ F. S. Hely, ${ }^{3} \odot$ I. van den Berg, ${ }^{1}{ }^{\oplus}$ \\ and J. E. Pryce ${ }^{1,2 *}$ (D) \\ ${ }^{1}$ Agriculture Victoria Research, AgriBio, Centre for AgriBioscience, Bundoora, Victoria 3083, Australia \\ ${ }^{2}$ School of Applied Systems Biology, La Trobe University, Bundoora, Victoria 3083, Australia \\ ${ }^{3}$ AbacusBio Limited, P.O. Box 5585, Dunedin, New Zealand
}

\section{ABSTRACT}

This research explores possible options to reduce greenhouse gas (GHG) emissions in the Australian dairy industry by (1) including an environmental component in the national breeding program and (2) estimating the economic and environmental impacts of implementation of the subsequent indexes. A total of 12 possible selection indexes were considered. These indexes were developed to predict changes in gross per-animal methane production (using 3 scenarios depending on availability and efficacy of a direct methane trait breeding value prediction) with 4 different carbon prices, integrating them into an augmentation of the current conventional national selection index. Although some economic response is lost with inclusion of the GHG subindexes in the Balanced Performance Index, options do exist where this loss is marginal and, even in scenarios where all selection pressure is based on the environmental weighting, economic progress is still made in all cases. When including environmental traits within an index, if a relatively low percentage of economic gain or index progression is sacrificed, then approximately 40 to $50 \%$ of the maximum possible reductions in emissions may be achieved. This concurrent selection of estimated breeding values that have a correlated favorable response in emissions in addition to direct selection on a residual methane trait allows a high level of methane reduction to be achieved with a realized cost to farmers that is far lower than the economic value placed on carbon. By implementing a GHG subindex in the national breeding program, we can achieve up to a $7.9 \%$ decrease in residual methane and 9 times the reduction in gross emissions in $10 \mathrm{yr}$, compared with the current breeding program, with

Received September 11, 2021.

Accepted December 22, 2021.

*Corresponding author: jennie.pryce@agriculture.vic.gov.au little to no cost to farmers. By 2050, selection based on one of the more moderate index scenarios at a carbon price of AUD $\$ 250 / \mathrm{t}$ (AUD $\$ 1=\mathrm{US} \$ 0.71)$, or opportunity cost to farmers of AUD $\$ 87.22$, will reduce gross emissions by $8.23 \%$ and emissions intensity by $21.25 \%$, therefore offering a mitigation strategy that will be effective at reducing emissions with little compromise to profit.

Key words: sustainability, methane emission, environment, economic impact, selection index

\section{INTRODUCTION}

In 2016, Australia committed to reduce greenhouse gas (GHG) emissions by 26 to $28 \%$ of 2005 levels by the year 2030 (Paris Agreement, 2016). This target relies largely on a decrease in the 3 major GHG, carbon dioxide $\left(\mathrm{CO}_{2}\right)$, methane, and nitrous oxide, which account for $81 \%, 10 \%$, and $7 \%$ of the global GHG inventory, respectively (https://www.epa.gov/ghgemissions/ overview-greenhouse-gases).

Enteric methane produced as a by-product of feed fermentation (Appuhamy et al., 2016) is the primary GHG targeted for reduction, as it accounts for $57 \%$ of the Australian dairy industry's emissions (UNFCCC, 2018). Genetic selection for lower enteric methane production may provide a permanent and cumulative solution to reduce GHG emissions, and several strategies could be incorporated into breeding programs to target a reduction in emissions (Wall et al., 2010; Basarab et al., 2013; Pryce and Haile-Mariam, 2020).

National selection indexes are a powerful tool for modifying the trajectory and rate of genetic change across multiple traits. These indexes are typically constructed with a focus on how traits are expected to influence the direct profitability or efficiency of production. For genetic selection to contribute to environmental gains, these national indexes will need to be expanded and modified to consider how existing and novel selection criteria can be optimally weighted to 
efficiently allocate selection efforts among traits that affect only profit, traits that affect only environmental outcomes, and traits that affect both (Boichard and Brochard 2012; Martin-Collado et al., 2015).

Three of the challenges in accommodating environmental traits are as follows: (1) identifying appropriate selection criteria that are available on a large number of selection candidates; (2) deriving meaningful weights for these selection criteria; and the focus of the current paper; and (3) evaluating the consequences of multitrait selection directly on the traits in the index and on other correlated traits.

Previous studies have investigated possible methane trait definitions (Breider et al., 2019; González-Reico et al., 2020; Manzanilla-Pech et al., 2021), and some of these may be suitable for inclusion in the Australian national dairy breeding objective (Richardson et al., 2021b). Richardson et al. (2021b) defined candidate enteric methane traits to reduce environmental impact without severely affecting other valuable traits such as production, health, and fertility within the context of the Australian national dairy breeding program. Under these criteria, a residual methane trait phenotypically corrected for energy-corrected milk was proposed due to its heritability $(0.21 \pm 0.10)$ and the potential ease of incorporating the trait within future indexes, as it is unexpected to have substantial correlations with other economically relevant traits. Emissions may also be reduced indirectly through correlated traits known to have a favorable effect on reducing enteric methane. Survival and feed saved (kg of DM/ yr; Pryce et al., 2015) are traits currently included in the national selection indexes that have been shown to reduce emissions due to their independent effects of reducing methane through fewer replacements and lower feed requirements, respectively (Richardson et al., 2021a).

Two selection indexes are commonly used by Australian dairy farmers: the Balanced Performance Index (BPI) and the Health Weighted Index (HWI). The $\mathrm{BPI}$ is an economic-based index aimed at improving the overall profit on farm, whereas the HWI places additional emphasis on fertility, health, and feed efficiency. Byrne et al. (2016) describe the index development, which was recently updated with current industry parameters and economic inputs (Axford et al., 2021). The HWI was developed by incorporating the 1000Minds approach (1000Minds Ltd., Dunedin, New Zealand), which also gives traits a noneconomic value-based farmer preference for improvements, reflecting the intrinsic interests of farmers separate from economics and profit (Martin-Collado et al., 2015). This willingness to sacrifice potential economic gains to achieve progress in traits related to management or social purposes is useful for deriving alternative index weights based not exclusively on economic benefits, such as for environmental traits. Although there is currently no predetermined economic value for carbon within Australia, social pressures to responsibly reduce emissions place a new pressure on the industry to adapt their farming practices, including modification of their genetic selection choices.

The effects of including an environmental component in the national selection index needs to be estimated before a strategy to reduce GHG through genetic selection can be efficiently implemented. The aim of this research was to explore possible options to reduce GHG emissions in the Australian dairy industry, using adapted versions of the BPI that include GHG subindexes developed using a combination of currently evaluated traits in addition to a direct residual methane trait, while maintaining a profitable dairy animal through (1) including an environmental component in the national breeding program and (2) estimating the economic and environmental impacts of implementation of the subsequent indexes.

\section{MATERIALS AND METHODS}

In Australia, the current primary national selection index is the BPI (Axford et al., 2021); therefore, the implementation of possible GHG subindexes within the BPI were examined and compared with the most recent BPI and HWI indexes, noting that HWI has more of a desired-gains approach that is focused on improving health and fertility traits. A total of 12 possible selection indexes were considered. These indexes were developed by including 3 variations of a GHG subindex: (1) considering current selection criteria alone, referred to as the base GHG subindex $\left(\mathbf{G H G}_{\text {index }}\right) ;(2)$ current criteria plus a novel but low-accuracy direct residual methane trait $\left(\mathbf{G H G}^{+}{ }_{\text {index }}\right)$; (3) current criteria plus a future higher-accuracy residual methane trait $\left(\mathbf{G H G}^{\mathrm{S}}{ }_{\text {index }}\right)$. For all versions, the subindexes were weighted according to their effect on gross methane per cow per lactation.

The 3 options were then evaluated when integrated into the current BPI index, with 4 different carbon prices used to maximize genetic progress in a holistic economic-based breeding goal. The environmental and economic impacts of the 12 index scenarios were estimated and compared with the 2 current national indexes. Additionally, selection solely on the GHG subindexes was considered, to determine the maximum magnitude of enteric residual methane reduction that could be achieved. 


\section{GHG Subindex Development}

A base GHG subindex, or $\mathrm{GHG}_{\text {index }}$, was previously developed as described by Richardson et al. (2021a). Briefly, gross emissions coefficients (GV; Table 1) were estimated that describe the change in enteric methane attributed to traits currently under selection in Australian dairy cattle (expressed in $\mathrm{CO}_{2}$ equivalents, $\mathbf{C O}_{2}$-eq). Because these GV coefficients were estimated to be independent, they can be used as weights within an index to place noneconomic emphasis on traits with environmental impact. The calculated GV coefficients were applied to existing EBV shown to have an independent effect on enteric methane emissions and used to develop $\mathrm{GHG}_{\text {index }}$, which has units of $\mathrm{CO}_{2}$-eq emitted per cow per year:

$$
\mathrm{GHG}_{\text {index }}=\sum_{n=1}^{i} G V_{i} \times E B V_{i}
$$

where $G V_{i}$ is the gross emissions coefficient ( $\mathrm{kg}$ of $\mathrm{CO}_{2}$-eq/yr) for trait $i$ (milk, fat, protein, survival, and feed saved) and $E B V_{i}$ is the EBV for trait $i$ (milk, fat, protein, survival, and feed saved).

A preliminary residual methane trait was added to the index to determine the effect of including a direct methane trait on reducing emissions (i.e., $\mathrm{GHG}^{+}$index) The residual methane trait ( $\mathrm{kg}$ of methane/yr) was previously developed by Richardson et al. (2021b) and defined as methane production phenotypically corrected for ECM. Thus, $\mathrm{GHG}^{+}{ }_{\text {index }}$ is as follows:

$$
\mathrm{GHG}^{+}{ }_{\text {index }}=\mathrm{GHG}_{\text {index }}+G V_{R M P} \times E B V_{R M P},
$$

where $G V_{R M P}$ is the gross methane coefficient for residual methane, and $E B V_{R M P}$ is the EBV for residual methane phenotypically corrected for ECM ( $\mathrm{kg}$ of methane/yr).

\section{Residual Methane Genomic EBV}

The genomic prediction equation to calculate $E B$ $V_{R M P}$ was estimated using a reference population of 464 Holstein cows from Ellinbank, Australia (Richardson et al., 2021b). Measurements for methane production were performed using the $\mathrm{SF}_{6}$ tracer method previously described by Deighton et al. (2014), which was then corrected phenotypically for ECM to produce the residual methane phenotypes (Richardson et al., 2021b) and calculated as follows:

$$
\mathrm{RMP}_{\mathrm{pECM}}=\mathrm{MeP}-\left(\mathrm{b}_{\mathrm{pECM}} \times \mathrm{ECM}\right),
$$

where $\mathrm{RMP}_{\mathrm{pECM}}$ is RMP phenotypically corrected for ECM, ECM is energy-corrected milk $(\mathrm{kg} / \mathrm{d}), \mathrm{b}_{\mathrm{pECM}}$ is the linear regression coefficient of MeP on ECM; and $\mathrm{MeP}$ is methane production. The effects of 41,276 SNP on the Illumina Bovine $50 \mathrm{~K}$ panel (Illumina Inc.) were estimated as $\hat{\beta}=\mu+\mathbf{Z}^{\prime}\left(\mathbf{Z Z}^{\prime}\right)^{-1} \hat{\mathbf{g}}$, where $\mathbf{Z}$ is the genotype matrix (464 individuals $\times 41,276 \mathrm{SNP}$ ), and $\hat{\mathbf{g}}$ is a vector of descaled direct genomic value estimated using GBLUP (VanRaden, 2008). The vector $\hat{\mathbf{g}}$ was applied to the genotypes of 3,412 Holstein bulls to calculate $E B V_{R M P}$. It was assumed that $E B V_{R M P}$ had an accuracy of 0.1 , as estimated in the independent cross-validation described by Richardson et al. (2021b).

All other EBV for the 3,412 registered Holstein bulls used in this study were provided by DataGene Ltd. (Bundoora, Victoria, Australia). Bulls were born between 2010 and 2015. The EBV used in this analysis included milk volume, milk fat, milk protein, survival, fertility, feed saved, mastitis resistance, somatic cell

\begin{tabular}{|c|c|c|c|c|c|c|}
\hline Trait & \multicolumn{3}{|c|}{ Gross emissions coefficient, ${ }^{1} \mathrm{~kg}$ of $\mathrm{CO}_{2}$-eq } & \multicolumn{3}{|c|}{ Relative emphasis, \% } \\
\hline Protein & 1.97 & 1.97 & 1.97 & 9.44 & 7.31 & 3.95 \\
\hline Milk & 0.04 & 0.04 & 0.04 & 8.34 & 6.93 & 3.74 \\
\hline Survival & -10.19 & -10.19 & -10.19 & 26.63 & 20.26 & 9.99 \\
\hline Feed saved & -0.53 & -0.53 & -0.53 & 23.26 & 20.66 & 14.75 \\
\hline
\end{tabular}

Table 1. Gross emissions coefficients ( $\mathrm{kg}$ of $\mathrm{CO}_{2}$ equivalents, $\mathrm{CO}_{2}$-eq) and subsequent relative emphasis for traits shown to have an independent effect of greenhouse gas (GHG) emissions in dairy cattle

${ }^{1}$ Gross emissions coefficients were previously calculated by Richardson et al. (2021a). GHG $_{\text {index }}$ was developed as described by Richardson et al. (2021c) and updated to include a gross emissions value for residual methane $\left(\mathrm{GHG}^{+}\right.$index $)$as well as a simulated residual methane trait with higher accuracy $\left(\mathrm{GHG}^{\mathrm{S}}\right.$ index $)$.

${ }^{2} \mathrm{RMP}$ is the residual methane production EBV as defined by Richardson et al. (2021b).

${ }^{3} \mathrm{RMPS}$ is the simulated residual methane production EBV with higher accuracy. 
count, milking speed, milking temperament, overall type, mammary system, pin set, and udder depth, and were extracted from the April 2020 national genetic evaluation. Details of the traits evaluated can be found on the DataGene website (www.datagene.com.au).

\section{Converting Residual Methane EBV to BPI Units}

Residual methane EBV were estimated in units of grams per day, taken as the recorded average daily methane emitted per cow after phenotypic adjustment for ECM. These EBV were rescaled to the units of the BPI and the GHG subindex. Because the BPI and HWI are annual measurements (i.e., the aggregate is a measure of profit per year), it was necessary to convert residual methane EBV from grams of methane per day to kilograms of methane per year. A conversion constant $(c)$ was defined as the number of full equivalent days of methane production (at the time of research data collection) per year and was calculated as

$$
c=t \times \sum\left(\frac{D M I_{i}}{D M I_{R}}\right),
$$

where $t$ is the time period to which the EBV is converted, $D M I_{i}$ is dry matter intake at $i$ days in milk, and $D M I_{R}$ is the DMI at the average days in milk when methane phenotypes were collected $(\mathrm{DIM}=113)$.

\section{Calculating Emissions Coefficient for Residual Methane}

The GV for residual methane was calculated as 1 $\mathrm{kg}$ of additional methane produced per 1-unit increase in residual methane, multiplied by the global warming potential of methane to carbon $(1 \mathrm{~kg}$ of methane $\times 28$ $\mathrm{CO}_{2}$-eq/1 kg of methane; Gerber et al., 2013).

\section{Simulating Residual Methane EBV}

One of the challenges of implementing a residual methane EBV in an index is the small number of phenotypes that are available on genotyped individuals, resulting in low accuracy of the performed genomic evaluation (Goddard et al., 2011). In the future, it is anticipated that additional phenotypes for methane will become available through various strategies, such as expanding data sets, or more extensive use of predictors.

To quantify the effect of future higher genomic prediction accuracies, an additional GHG subindex (i.e., $\mathrm{GHG}_{\text {index }}^{\mathrm{S}}$ ) was investigated to determine the influence of including a more accurate residual methane trait into the GHG subindex and subsequently the BPI. Residual methane EBV were simulated, based on the expected accuracy of a residual methane trait with a heritability of 0.21 (Richardson et al., 2021b) and reference population sizes of 1,000,3,000,5,000, 10,000, 50,000, and 100,000 animals, using methods described by Goddard et al. (2011).

Using the formula proposed by Goddard et al. (2011), it was assumed that the predicted accuracy can be estimated as $r=\sqrt{\frac{\theta}{1+\theta-r^{2} h^{2}}}$ with $\theta=\frac{T h^{2}}{M_{e}}$, where $T$ is the size of the reference population, $h^{2}$ the trait heritability, and $M_{e}$ the effective number of independent chromosome segments (Table 2). $M_{e}$ can be estimated using the effective population size and chromosome segment length. We assumed an effective population size of 100 and a chromosome length of 30 (Zimin et al., 2009). Residual methane EBV were simulated using the rnorm_pre() function in $\mathrm{R}$ ( $\mathrm{R}$ Core Team, 2021) by multiplying the predicted accuracy for a reference population size of 3,000 animals with the standard deviation of the previously estimated residual methane EBV and assuming a correlation of 0.4 between residual methane and liveweight (Breider et al., 2019). The simulated residual methane trait was then added to the base GHG index using the estimated GV for residual methane to develop the simulated GHG subindex, $\mathrm{GHG}_{\text {index }}^{\mathrm{S}}$, and defined as

$$
\mathrm{GHG}_{\text {index }}^{\mathrm{S}}=\mathrm{GHG}_{\text {index }}+G V_{R M P} \times E B V_{S . R M P}
$$

where $G V_{R M P}$ is the gross methane coefficient for residual methane, and $E B V_{S . R M P}$ is the simulated residual methane EBV with a higher accuracy through the increased reference population size (3,000 animals).

Table 2. Parameters used to estimate prediction accuracy, using methods described by Goddard et al. (2011)

\begin{tabular}{lcl}
\hline Constant & Value & Reference \\
\hline Heritability, residual methane & 0.21 & Richardson et al., 2021b \\
Chromosome segment length (LN. Chr) & 30 & Zimin et al., 2009 \\
Effective population size (Ne) & 100 & Zimin et al., 2009 \\
Effective number of independent chromosome segments (Me) & $1,132.43$ & \\
Prediction accuracy of cross-validation & 0.1 & Richardson et al., 2021b \\
\hline
\end{tabular}


Table 3. Weight and relative emphasis of the greenhouse gas (GHG) index when included within the Balanced Performance Index (BPI) at carbon price of $\operatorname{AUD} \$ 150 / \mathrm{t}, \mathrm{AUD} \$ 250 / \mathrm{t}, \mathrm{AUD} \$ 500 / \mathrm{t}$, and $\mathrm{AUD} \$ 1,000 / \mathrm{t}$

\begin{tabular}{|c|c|c|c|c|c|c|c|c|}
\hline Scenario $^{1}$ & \multicolumn{4}{|c|}{ Index weight } & \multicolumn{4}{|c|}{ Relative emphasis } \\
\hline BPI.2 & -0.15 & -0.25 & -0.50 & -1.00 & 4.41 & 6.39 & 13.39 & 23.56 \\
\hline BPI.3 & -0.15 & -0.25 & -0.50 & -1.00 & 8.20 & 11.43 & 23.67 & 41.40 \\
\hline
\end{tabular}

${ }^{1}$ BPI.1, BPI.2 and BPI.3 describe scenarios where $\mathrm{GHG}_{\text {index }}, \mathrm{GHG}^{+}{ }_{\text {index }}$, and $\mathrm{GHG}_{\text {index }}^{\mathrm{S}}$ have been included in the BPI, respectively. GHG $\mathrm{index}_{\text {was }}$ developed as described by Richardson et al. (2021c) and updated to include a gross emissions value for residual methane $\left(\mathrm{GHG}^{+}{ }_{\text {index }}\right)$ as well as a simulated residual methane trait with higher accuracy $\left(\mathrm{GHG}^{\mathrm{S}}\right.$ index $)$.

\section{Inclusion in National Selection Index}

The 3 GHG subindexes were included in the BPI with 4 different carbon prices driving the economic weighting applied to methane. The 3 scenarios represent the scenarios when no or insufficient records for residual methane are available (BPI.1), using the data currently available for residual methane (BPI.2), and a scenario with an increased accuracy of residual methane EBV (BPI.3). The investigated index scenarios were as follows:

$$
\begin{aligned}
& \text { BPI.1 }=B P I+\left(E V_{C} \times G H G_{\text {index }}\right) ; \\
& \text { BPI.2 }=B P I+\left(E V_{C} \times G H G^{+}{ }_{\text {index }}\right) ; \\
& \text { BPI.3 }=B P I+\left(E V_{C} \times G H G^{S}{ }_{\text {index }}\right),
\end{aligned}
$$

where the component indexes are as previously described, and $E V_{C}$ is the carbon price at $\operatorname{AUD} \$ 150$, $\operatorname{AUD} \$ 250, \operatorname{AUD} \$ 500$, and $\operatorname{AUD} \$ 1,000 / \mathrm{t} \quad(\operatorname{AUD} \$ 1=$ US\$0.71). Considerable variation currently exists in the price of carbon and future predictions of that price; for example, AUD $\$ 55 / \mathrm{t}$ has been used as the price in Canada (Government of Canada, 2021), whereas studies of the true long-term cost of carbon have produced much higher values, up to AUD $\$ 550$ depending on the country, year, and sector of implementation (Stern and Stiglitz, 2021; World Bank, 2021). The effect of using the GHG subindexes as independent selection tools separate from the BPI was also explored.

\section{GHG Subindex Included in National Indexes}

The weights applied to traits included within BPI.1, BPI.2, and BPI.3 are presented in 2 ways. First, as the relative weight that the GHG subindex receives within the BPI (Table 3), and, second, as the total weight that each trait will receive when a GHG subindex is included in the BPI by combining both the economic and environmental weights (Table 4). For example, the final weight of protein within BPI.1 is equal to the economic value of protein (AUD \$6.76), which is the current weight protein receives in BPI, plus additional emphasis provided by converting the GV into an economic value using the respective carbon price. For example, in the scenario where the carbon price is $\mathrm{AUD} \$ 150 / \mathrm{t}$, it was calculated as $1.97 \mathrm{~kg} \mathrm{CO}$-eq $/ \mathrm{kg}$ protein $\times-0.15 / \mathrm{kg} \mathrm{CO}_{2}$-eq.

\section{Relative Emphasis}

The relative emphasis of each trait and subindexes for every variant of the BPI was calculated using the approach of Zhang et al. (2021), which accounts for the accuracy of the EBV as well as the (favorable or antagonistic) relationships between traits in contrast to traditional approaches that are often a simple multiplication of the relative contribution of each trait's economic value (converted to absolute value) by its genetic standard deviation (SD). Here, we applied the method of Zhang et al. (2021) using correlations between the EBV. The resulting trait emphasis values more accurately present the true selection pressure each trait receives within the given index.

\section{Environmental and Economic Response to Selection}

Current and future rates of genetic progress in novel GHG traits and subindexes were modeled using EBV for Australian dairy cattle. A regression analysis was used to compare selection on the BPI options that integrate GHG subindexes with the response expected from selection on BPI alone. Scott et al. (2021) reported that the annual rate of genetic gain in BPI since 2013 ranged between 0.11 and 0.22 genetic SD per year for Holstein cows and bulls, respectively. Consequently, we assumed that a 1-SD improvement (AUD\$84.06; Axford et al., 2021) in BPI would be achieved over around $10 \mathrm{yr}$ of selection. The responses in BPI units achieved by selection on each of the considered indexes, as well as the total $\mathrm{CO}_{2}$-eq reduction achieved by selection for each index, are presented. 


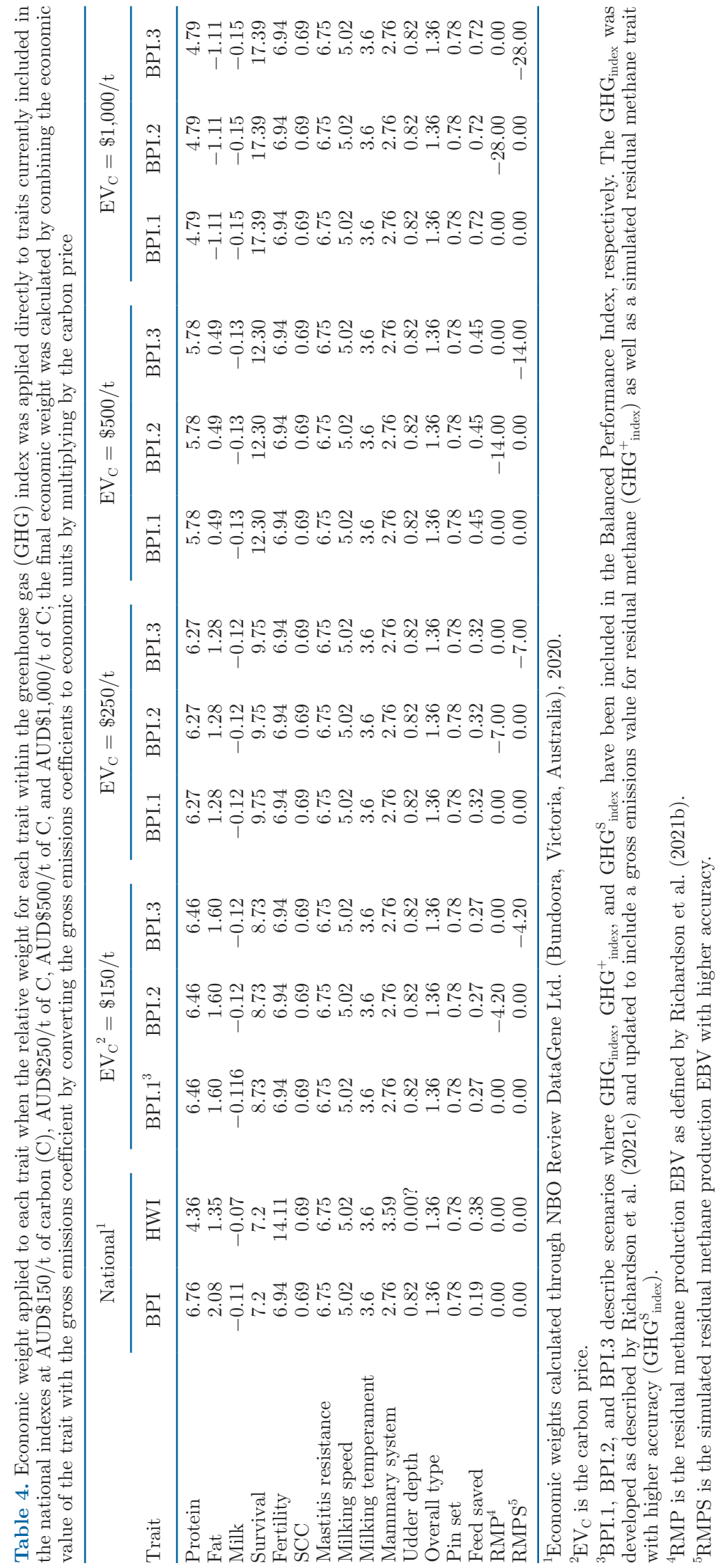


The opportunity costs of carbon emissions reductions, or costs to farmers, achieved through breeding for each index with emphasis on emissions were derived by taking the ratio of the reduction in BPI units achieved in AUD \$ per cow per year relative to the emissions reduction in $\mathrm{CO}_{2}$-eq per cow per year when compared with the same index without any emphasis on emissions, as follows:

$$
\text { OpportunityCost }_{i}=\frac{\Delta \text { IndexGain }(\$)}{\Delta \text { EmissionsReduction }} \times 1,000 \mathrm{~kg} / \mathrm{t},
$$

where $\Delta$ IndexGain is the difference in the economic response to selection (AUD\$/SD BPI) between the primary index (BPI) and the ith selection index and $\Delta$ EmissionsReduction is the difference in emissions response to selection ( $\mathrm{kg}$ of $\mathrm{CO}_{2}$-eq/SD BPI) between the primary index (BPI) and the proposed $i$ th selection indexes. The selection indices evaluated as $i$ were HWI, $\mathrm{GHG}_{\text {index }}, \mathrm{GHG}^{+}{ }_{\text {index }}, \mathrm{GHG}^{\mathrm{S}}{ }_{\text {index }}$, as well as BPI.1, BPI.2, and BPI.3 at carbon prices of AUD $\$ 150 / t, A U D \$ 250 / t$, AUD $\$ 500 / \mathrm{t}$, and AUD $\$ 1,000 / \mathrm{t}$.

\section{RESULTS}

\section{Relative Percent Emphasis of GHG Subindexes}

By constructing subindexes that include traits weighted based on their independent effects on emissions, we calculated the relative emphasis of each trait within the GHG subindexes (Table 1). Here we tested (1) milk, fat, protein, survival, and feed saved EBV as $\mathrm{GHG}_{\text {index }},(2)$ added an estimated residual methane trait as $\mathrm{GHG}^{+}$index , and (3) included a simulated residual methane trait as $\mathrm{GHG}^{\mathrm{S}}{ }_{\text {index }}$, resulting in the following:

(1) In $\mathrm{GHG}_{\text {index }}$, fat yield had the largest relative emphasis at $32 \%$, with survival and feed saved contributing $27 \%$ and $23 \%$, respectively. Protein $(10 \%)$ and milk $(8 \%)$ were more moderately weighted within the $\mathrm{GHG}_{\text {index }}$.

(2) When an estimated residual methane trait was added to the $\mathrm{GHG}^{+}{ }_{\text {index }}$, the relative weights shifted to residual methane having the largest emphasis (26\%), with survival (20\%), feed saved $(21 \%)$, and fat $(19 \%)$ having the next largest relative emphasis within the subindex. Milk and protein remained moderately weighted at $7 \%$.

(3) The inclusion of a simulated residual methane trait with a higher accuracy further increased the relative emphasis of residual methane to
$57 \%$ within $\mathrm{GHG}^{\mathrm{S}}$ index. Feed saved had the next largest emphasis at $15 \%$, with survival and fat having a moderate emphasis of $10 \%$. Milk and protein had small emphasis at $4 \%$.

\section{Relative Emphasis of GHG Subindexes and Component Traits Within BPI}

The next step was to augment the BPI to include the 3 subindexes described in the previous section; the economic weights in each of GHG subindex included in the BPI at varying carbon prices are presented in Table 3. At an economic value of AUD $\$ 150 / t$ of carbon the $\mathrm{GHG}_{\text {index }}, \mathrm{GHG}^{+}$index , and $\mathrm{GHG}_{\text {index }}^{\mathrm{S}}$ received $3.77 \%$, $4.40 \%$, and $8.2 \%$ of the total selection emphasis within BPI, respectively. These relative weights increased proportional to the economic values placed on carbon of AUD $\$ 500 / t$ and AUD $\$ 1,000 / t$ in the $\mathrm{GHG}_{\text {index }}(10.57 \%$ and $20.01 \%$, respectively), $\mathrm{GHG}^{+}$index $(13.39 \%$ and $23.56 \%)$, and $\mathrm{GHG}^{\mathrm{S}}{ }_{\text {index }}(23.67 \%$ and $41.40 \%)$.

The GHG subindexes are composed of EBV routinely evaluated in Australia, as well as a residual methane trait. The economic weights and subsequent relative emphasis of each trait within the BPI as a result of including the GHG subindexes are presented in Tables 4 and 5 , respectively. Briefly, as the price of carbon increased, additional emphasis shifted onto fertility, survival, mastitis resistance (and SCC), and feed saved, whereas relative emphasis was lowered for production and type traits.

\section{Predicted Accuracy}

The predicted accuracies of a residual methane trait with various reference population sizes are presented in Figure 1. The predicted accuracy of the residual methane trait ranged from $0.36(\mathrm{n}=1,000)$ to $0.88(\mathrm{n}=$ 100,000). For a reference population of 3,000 animals, which was used to simulate the residual methane trait used as part of $\mathrm{GHG}_{\text {index }}^{\mathrm{S}}$, the predicted accuracy was 0.54 .

\section{Economic Response}

The economic responses to selection on each index for a 1-SD improvement in BPI, or approximately 10 yr of selection, equivalent to AUD $\$ 84.06$ BPI units (\$AUD per cow per year), are presented in Figure 2. When the equivalent selection pressure of $1 \mathrm{SD}$ of BPI was applied to HWI, the economic response (in BPI units) was AUD $\$ 76.57$. Minimal change in economic response was observed when the $\mathrm{GHG}_{\text {index }}$ (AUD\$83.34), $\mathrm{GHG}^{+}{ }_{\text {index }}(\mathrm{AUD} \$ 83.08)$, and $\mathrm{GHG}^{\mathrm{S}}$ index 


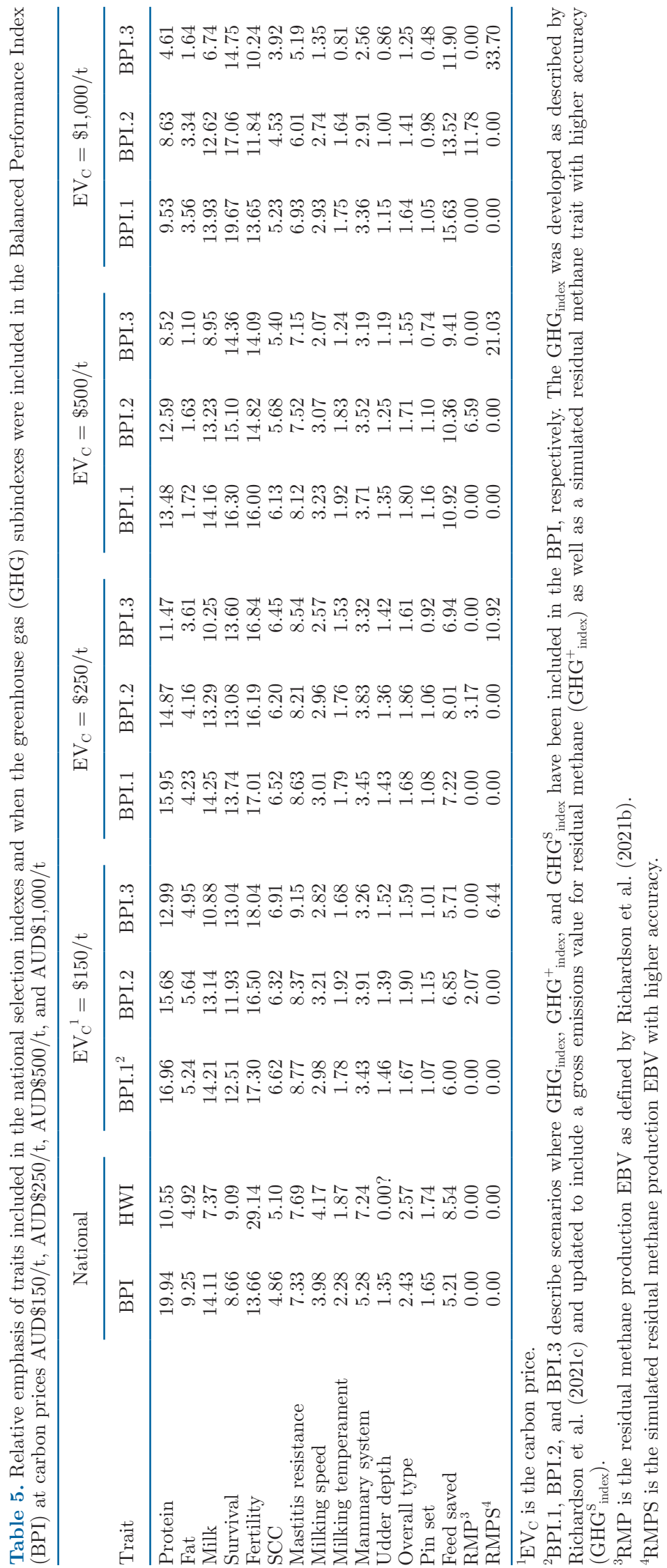


(AUD \$80.37) were included in the BPI at a carbon price of AUD $\$ 150 / t$ of carbon, and when $\mathrm{GHG}_{\text {index }}$ and $\mathrm{GHG}^{+}{ }_{\text {index }}$ were included in BPI at a carbon price of $\mathrm{AUD} \$ 250 / \mathrm{t}$ (AUD $\$ 82.18$ and AUD $\$ 81.50$, respectively). An economic response similar to the HWI was observed when $\mathrm{GHG}^{\mathrm{S}}$ index $(\mathrm{AUD} \$ 75.53$ ) was included in the BPI at a carbon price of AUD $\$ 250 / t$ and when $\mathrm{GHG}_{\text {index }}$ and $\mathrm{GHG}^{+}$index were included at a carbon price of $\mathrm{AUD} \$ 500 / \mathrm{t}(\mathrm{AUD} \$ 77.84$ and AUD $\$ 75.72)$. A lower economic response was observed when $\mathrm{GHG}^{\mathrm{S}}$ index (AUD \$63.03) was included in the BPI at a carbon price of $\mathrm{AUD} \$ 500 / \mathrm{t}$ and for the $\mathrm{GHG}_{\text {index }}$ and $\mathrm{GHG}^{+}$index at a carbon price of $\operatorname{AUD} \$ 1,000 / \mathrm{t}$ (AUD $\$ 67.62$ and AUD \$62.96).

The lowest economic response (AUD \$47.11) was observed when $\mathrm{GHG}^{\mathrm{S}}$ index was included in the BPI at a carbon price of AUD $\$ 1,000 / \mathrm{t}$. Interestingly, economic responses of AUD $\$ 20.73$, AUD $\$ 15.37$, and AUD $\$ 18.08$ were estimated for selection solely on the $\mathrm{GHG}_{\text {index }}$, $\mathrm{GHG}^{+}$index, and $\mathrm{GHG}^{\mathrm{S}}$ index, respectively. For these indexes, significant genetic progress is achieved in fertility and survival, but at the expense of genetic progress in milk production traits (Table 5). Although economic response is lost with inclusion of the GHG subindexes in the BPI, options do exist where this loss is marginal, and, even in scenarios where all selection pressure is based on the environmental weighting, economic progress is still made in all cases.

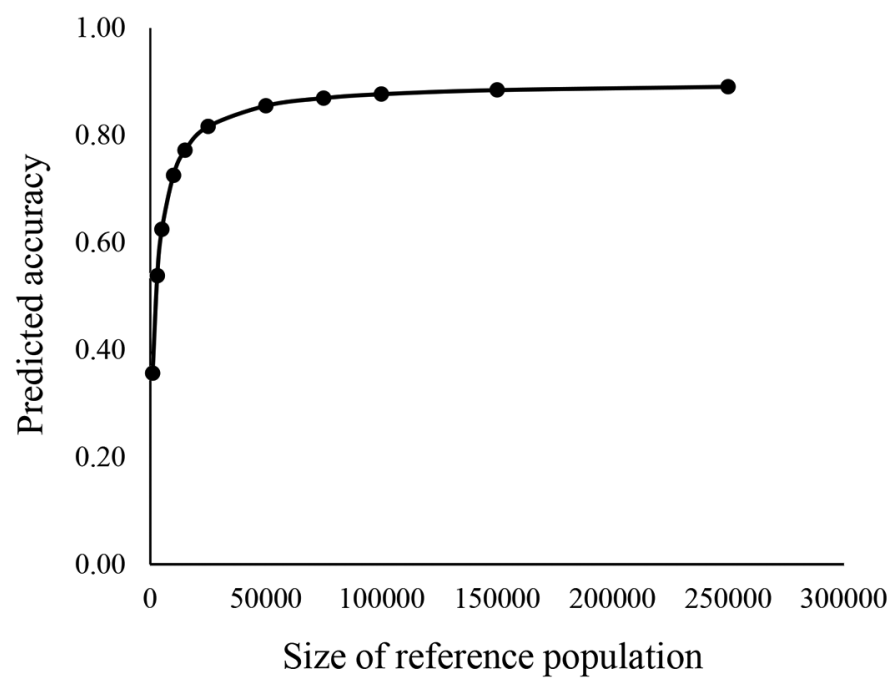

Figure 1. Prediction accuracy of a simulated residual methane trait phenotypically corrected for ECM. Accuracy was predicted using methods described by Goddard et al. (2011), assuming a heritability of 0.21 , chromosome segment length of 30 , and effective population size of 100 .

\section{Environmental Response}

The expected reduction in emissions due to selection on each index with a selection intensity equivalent to $1 \mathrm{SD}$ of BPI are presented in Figure 3, in kilograms of $\mathrm{CO}_{2}$-eq. The environmental reduction estimated for selection on BPI and HWI was $19.45 \mathrm{~kg}$ of $\mathrm{CO}_{2}$-eq and $42.80 \mathrm{~kg}$ of $\mathrm{CO}_{2}$-eq per cow per BPI SD, respectively. The reductions as a result of selection for PBI.1 and BPI.2 were similar, with carbon prices of AUD $\$ 150 / \mathrm{t}$ $\left(29.28 \mathrm{~kg}\right.$ of $\mathrm{CO}_{2}$-eq and $29.93 \mathrm{~kg}$ of $\mathrm{CO}_{2}$-eq, respectively), $\mathrm{AUD} \$ 250 / \mathrm{t}\left(35.08 \mathrm{~kg}\right.$ of $\mathrm{CO}_{2}$-eq and $37.82 \mathrm{~kg}$ of $\mathrm{CO}_{2}$-eq), $\mathrm{AUD} \$ 500 / \mathrm{t}\left(46.86 \mathrm{~kg}\right.$ of $\mathrm{CO}_{2}$-eq and 37.82 $\mathrm{kg}$ of $\left.\mathrm{CO}_{2}-\mathrm{eq}\right)$, and $\mathrm{AUD} \$ 1,000 / \mathrm{t}\left(61.06 \mathrm{~kg}\right.$ of $\mathrm{CO}_{2^{-}}$ eq and $71.38 \mathrm{~kg}$ of $\mathrm{CO}_{2}$-eq). The emissions reduction due to selection for BPI.3 was considerably higher at $92.69 \mathrm{~kg}$ of $\mathrm{CO}_{2}$-eq, $117.25 \mathrm{~kg}$ of $\mathrm{CO}_{2}$-eq, $152.20 \mathrm{~kg}$ of $\mathrm{CO}_{2}$-eq, and $175.19 \mathrm{~kg}$ of $\mathrm{CO}_{2}$-eq when the carbon price was AUD $\$ 150 / t, \operatorname{AUD} \$ 250 / t, \operatorname{AUD} \$ 500 / t$, and AUD $\$ 1,000 / t$, respectively. Selection solely on $\mathrm{GHG}_{\text {index }}$, $\mathrm{GHG}^{+}$index, and $\mathrm{GHG}^{\mathrm{S}}$ index resulted in emissions reductions per cow per BPI SD of $78.88 \mathrm{~kg}$ of $\mathrm{CO}_{2}$-eq, 90.54 $\mathrm{kg}$ of $\mathrm{CO}_{2}$-eq, and $188.51 \mathrm{~kg}$ of $\mathrm{CO}_{2}$-eq, respectively.

The change in residual methane follows the same pattern, as presented in Figure 4, with selection on BPI resulting in the lowest reduction in a direct methane trait $\left(0.75 \mathrm{~kg}\right.$ of $\mathrm{CO}_{2}$-eq) and selection for BPI.3 at an economic value of AUD $\$ 1,000 / t$ resulting in the largest reduction in residual methane $\left(4.57 \mathrm{~kg}\right.$ of $\mathrm{CO}_{2}$-eq). For all carbon prices, the simulated residual methane trait with higher accuracy resulted in significantly larger reductions in methane emissions, whereas the reduction of direct methane via selection for the currently estimated residual methane trait was marginal.

\section{Opportunity Cost of Carbon to Farmers}

For all scenarios investigated, the opportunity cost of carbon to farmers was far below the actual carbon price (Figure 5). The costs of carbon experienced by farmers were AUD $\$ 73.25$ and AUD $\$ 120.28$ for BPI.1, AUD $\$ 93.51$ and AUD $\$ 139.36$ for BPI.2, and AUD $\$ 50.38$ and AUD $\$ 87.22$ for BPI.3 at carbon prices of AUD $\$ 150 / t$ and AUD $\$ 250 / t$, respectively. The ratio of the cost to the farmer relative to the carbon price became substantially smaller as the carbon price increased and when a higher-accuracy residual methane trait was included in the national index scenarios, such as BPI.3. At a carbon price of AUD $\$ 500 / t$, the costs of carbon to the farmer were AUD $\$ 226.92$, AUD $\$ 244.50$, and $\$ 58.42$ for BPI.1, BPI.2, and BPI.3, respectively. When the carbon price was AUD $\$ 1,000 / \mathrm{t}$, the costs of carbon to the farmer were AUD $\$ 395.10$ for BPI.1 


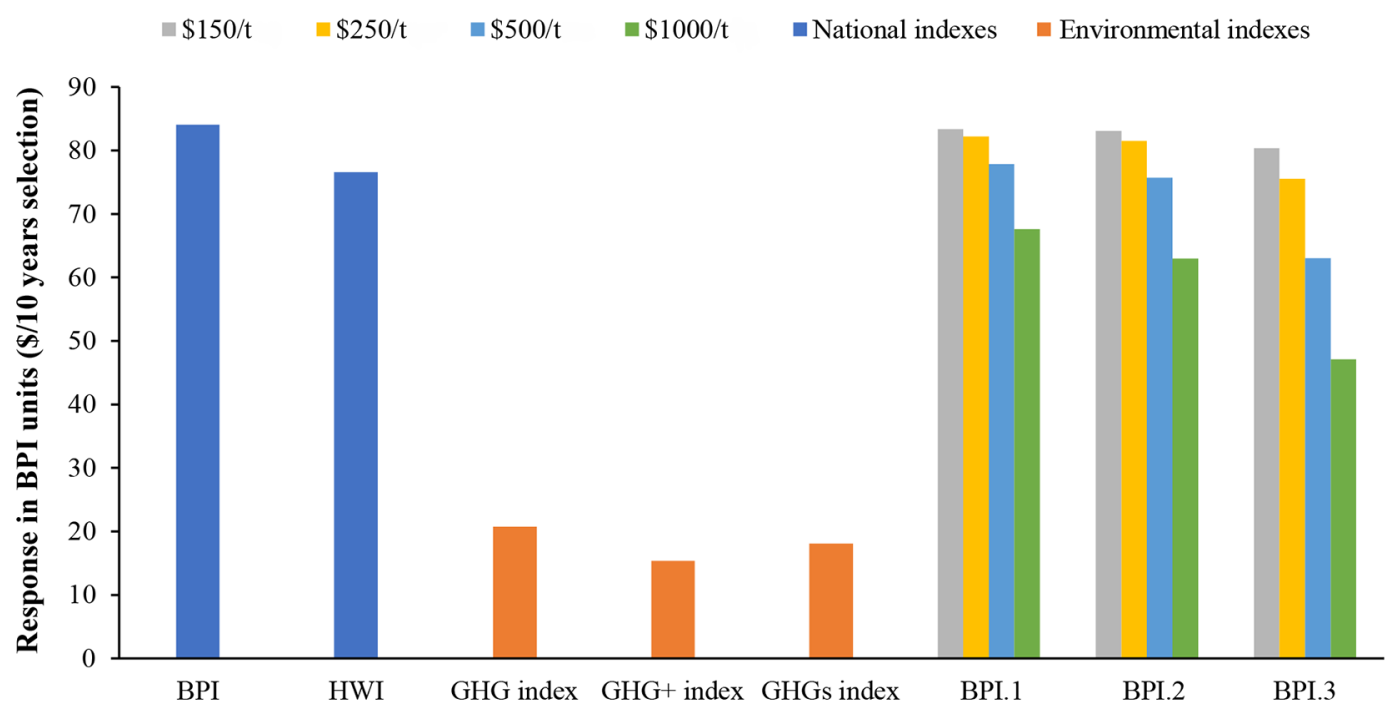

Figure 2. Economic responses to selection on each index for a 1-SD improvement in the Balanced Performance Index (BPI) or approximately $10 \mathrm{yr}$ of selection, equivalent to AUD $\$ 84.06$, as BPI units are $\$$ AUD per cow per year, at carbon prices of $\$ 150 / \mathrm{t}$ (gray), $\$ 250 / \mathrm{t}$ (yellow), $\$ 500 / \mathrm{t}$ (light blue), and $\$ 1,000 / \mathrm{t}$ (green). HWI $=$ Health Weighted Index. The $\mathrm{GHG}_{\text {index }}$ was developed as described by Richardson et al. (2021c) and updated to include a gross emissions value for residual methane $\left(\mathrm{GHG}^{+}{ }_{\text {index }}\right)$ as well as a simulated residual methane trait with higher accuracy $\left(\mathrm{GHG}_{\text {index }}^{\mathrm{S}}\right)$. BPI.1, BPI.2, and BPI.3 describe scenarios where the $\mathrm{GHG}_{\text {index }}$, $\mathrm{GHG}^{+}{ }_{\text {index }}$, and $\mathrm{GHG}_{\text {index }}^{\mathrm{S}}$ have been included in the BPI, respectively.

and AUD $\$ 406.32$ for BPI.2. The scenario that resulted in the most advantageous carbon cost for farmers was selection on BPI.3 at a carbon price of $\operatorname{AUD} \$ 1,000 / t$, where the opportunity cost of carbon to farmers was only $24 \%$ of the dictated carbon price at AUD $\$ 237.25$. Contrastingly, the cost of carbon for farmers when selecting for HWI was AUD\$320.77, meaning that the level of reduction achieved through selection on HWI is the equivalent of applying a carbon price of AUD\$320.77.

\section{DISCUSSION}

The national index scenarios presented in this study represent viable possible options for current and future strategies to reduce gross emissions in Australian dairy cattle. The results indicate that incorporating an environmental index into the BPI would lead to a reduction in GHG emissions without a major reduction in profit, especially when an accurate residual methane trait is available.

There are currently 1.4 million dairy cows in Australia (Newton et al., 2020), and, at a national level, the inclusion of a GHG subindex into BPI would represent a substantial reduction in $\mathrm{CO}_{2}$-eq. The average dairy cow in Australia produces roughly 4,298 $\mathrm{kg}$ of $\mathrm{CO}_{2}$-eq and $58.06 \mathrm{~kg}$ of residual methane per year, based on the average residual methane produced per day $(0.183$ $\mathrm{g}$ of methane; Richardson et al. 2021b) and the $c$ constant estimated in this study $(c=317 d)$. Although the per-animal reduction in emissions appears small for the options tested that are available to implement immediately $\left(29.28-71.38 \mathrm{~kg}\right.$ of $\mathrm{CO}_{2}$-eq and $0.88-1.22 \mathrm{~kg}$ of residual methane; Figures 3 and 4), the reduction has a substantial effect for the industry in terms of meeting reduction plans at the national herd level. A much larger per-animal reduction in emissions (92.69-175.19 $\mathrm{kg}$ of $\mathrm{CO}_{2}$-eq and $2.19-4.57 \mathrm{~kg}$ of residual methane) may be achieved in the near future through selection on BPI.3, when a more accurate methane EBV becomes available. By implementing a GHG subindex in the national breeding program, we can achieve up to a $7.9 \%$ decrease in residual methane (Figure 5) and 9 times the reduction in gross emissions compared with the current breeding program, with little to no cost to farmers.

Assuming a per-cow current emissions output of $4,297.86 \mathrm{~kg}$ of $\mathrm{CO}_{2}$-eq, an average production level of $339.29 \mathrm{~kg}$ of protein equivalents, a national herd size of 1.4 million cows, and current trait genetic trends (Richardson et al., 2021c), the reduction in gross emissions and emissions intensity that may be achieved through genetic selection was estimated for 10,30 , and $50 \mathrm{yr}$ of genetic selection (Table 6). Using these parameters, gross emissions may be decreased by $2.78 \%, 8.23 \%$, and $13.68 \%$ after 10,30 , and $50 \mathrm{yr}$ of genetic selection for BPI.3 at a carbon price of AUD $\$ 250 / t$; however, this translates to a cost to the farmer of AUD $\$ 87.22 / \mathrm{t}$. Interestingly, emissions intensity (EI) may be decreased by $7.84 \%, 21.25 \%$, and $32.34 \%$ after 10,30 , and $50 \mathrm{yr}$ of genetic selection for BPI.3 at the same carbon price, 


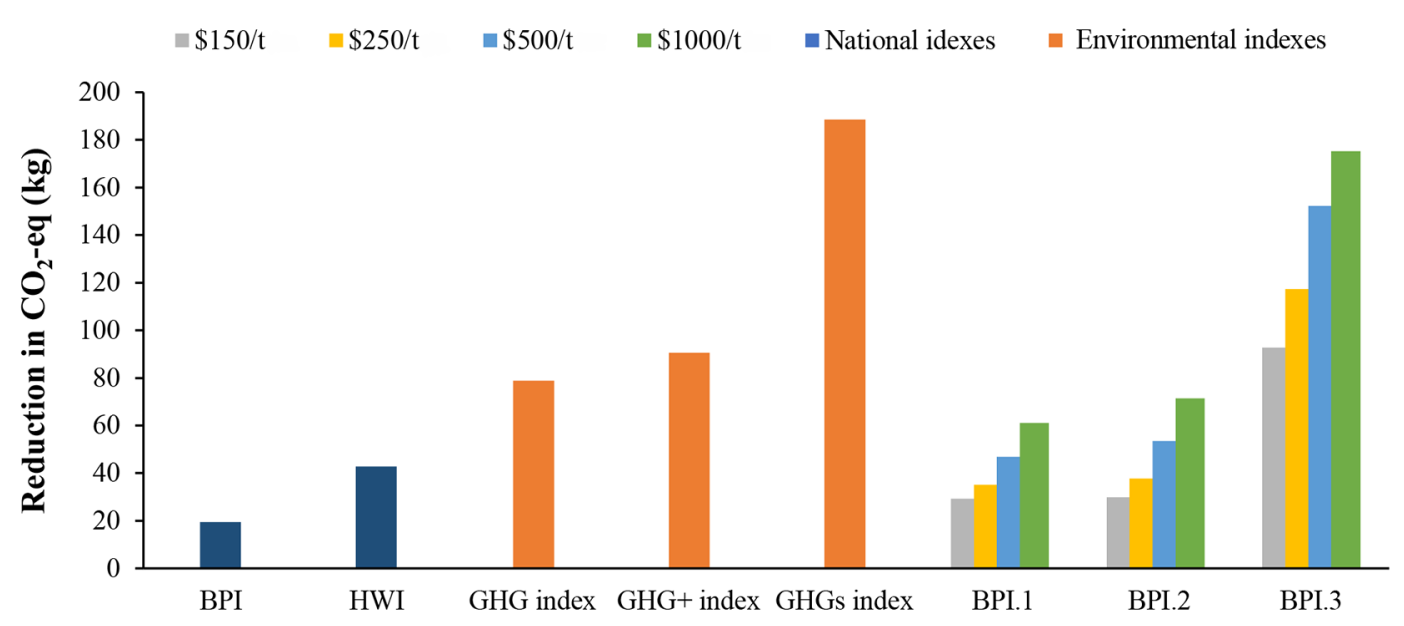

Figure 3. Environmental response in $\mathrm{kg}$ of $\mathrm{CO}_{2}$ equivalents $\left(\mathrm{CO}_{2}\right.$-eq) per cow per year, based on selection on each index for a 1-SD improvement in the Balanced Performance Index (BPI) or approximately $10 \mathrm{yr}$ of selection, equivalent to AUD $\$ 84.06$, as BPI units are \$AUD per cow per year, at carbon prices of $\$ 150 / \mathrm{t}$ (gray), $\$ 250 / \mathrm{t}$ (yellow), $\$ 500 / \mathrm{t}$ (light blue), and $\$ 1,000 / \mathrm{t}$ (green). HWI $=$ Health Weighted Index. The $\mathrm{GHG}_{\text {index }}$ was developed as described by Richardson et al. (2021c) and updated to include a gross emissions value for residual methane $\left(\mathrm{GHG}^{+}{ }_{\text {index }}\right)$ as well as a simulated residual methane trait with higher accuracy $\left(\mathrm{GHG}_{\text {index }}^{\mathrm{S}}\right)$. BPI.1, BPI.2, and BPI.3 describe scenarios where the $\mathrm{GHG}_{\text {index }}, \mathrm{GHG}^{+}{ }_{\text {index }}$, and $\mathrm{GHG}^{\mathrm{S}}$ index have been included in the BPI, respectively.

which is consistent with the $24 \%$ reduction in EI by 2050 reported by de Haas et al. (2021).

\section{Reduction in GHG}

The largest reduction in emissions was observed when selection was based solely on ranking animals by the GHG subindexes and disregarding the current national breeding objective (Figure 3). However, a similar reduction in emissions was achieved when residual methane with an accuracy reasonable for implementation (0.54) was included in the index. For the versions of BPI tested, BPI.3, which included the $\mathrm{GHG}^{\mathrm{S}}$ index, shows the largest reduction in kilograms of $\mathrm{CO}_{2}$-eq. This reduction was largely due to (1) the GV applied to residual methane and (2) including a higher-accuracy methane trait, causing residual methane to receive a considerable amount of relative emphasis within the GHG subindex. Residual methane has a global warming potential of 28, so whereas protein, for example, has a GV of 1.97 , residual methane has a GV of 28 . This causes a residual methane trait to be the largest driving force within the $\mathrm{GHG}^{\mathrm{S}}$ index. Additionally, the higher accuracy allows for greater selection intensity to be applied, resulting in a greater response to selection in residual methane and subsequently in the $\mathrm{GHG}^{\mathrm{S}}$ index.

\section{Short-Term Index Implementation to Reduce GHG}

To the best of our knowledge, no residual methane EBV for livestock with an accuracy appropriate for industry implementation is available anywhere in the world. Therefore, for the sake of a practical outcome, we will focus on considering the differences in environmental and economic changes between BPI.1 and BPI.2 for consideration as viable options for short-term implementation. The least computationally complex index is BPI.1, which includes the GHG subindex, composed entirely of currently estimated EBV. This index transitions relative emphasis from production and conformation traits onto traits related to survival, health, and efficiency by converting environmental coefficients into economic values. For implementation, this method takes advantage of the current genetic evaluation system and requires no additional EBV to be estimated. However, this method does not consider or fully capture the variation that exists in methane emissions between animals. As shown by our results, the current residual methane trait does not have much advantage in reducing emissions when compared with BPI.1, primarily due to its low reliability. A much larger reference population is required to reach the accuracy for implementation, particularly when such novel traits are developed using a female-driven reference population (Gonzalez-Recio et al., 2014). Although selecting for BPI.2 may not be substantially advantageous in terms of economic and environmental benefit, it does offer additional social benefits, such as maintaining the industry's social license to operate, by including the current residual methane trait at a lower accuracy. Therefore, until a sufficient amount of methane data is collected, BPI.1 is the most practical option in terms of economic and environmental benefit of the scenarios investigated to reduce emissions. 


\section{Prediction Accuracy and Reference Population Size}

The goal of including a simulated trait within the GHG subindex was to demonstrate the level of emissions reduction that may be achieved by a trait with a reasonable accuracy for implementation in Australia, using a reference population size that may be reached in the near future. For estimating the accuracy of a methane trait in the future, we assumed that a reference population of 3,000 animals was reasonable; our assumption was based on comparable international collaborations used, for example, for genetic evaluations of feed saved (Bolormaa et al., 2021). Although pooling of international databases has proved to be more challenging due to the various trait definitions and apparatuses used for collecting raw data (de Haas et al., 2017), recent efforts have been successful in using an international multitrait genomic prediction for various definitions of methane (Manzanilla-Pech et al., 2021).

The challenge in implementing a GHG subindex that includes a novel trait, such as residual methane, is the building and maintenance of a reference population that is representative of the national population and sufficient to estimate accurate EBV. The feed saved and residual methane EBV are reliant to some extent on international data sharing (Pryce et al., 2015; Richardson et al., 2021b). Data-sharing risks and genotype $x$ environment interactions might mean it is prudent to focus data collection within country, although this is expensive unless easy-to-measure selection criteria can be found.

The method used in Australia to measure methane phenotypes $\left(\mathrm{SF}_{6}\right.$; Deighton et al., 2014) is expensive, labor-intensive, and nearly impossible to implement on commercial farms. Another option is to include additional selection criteria, such as mid-infrared spectroscopy (Vanlierde et al., 2018), the heritable part of the microbiome (Zhang et al., 2020), feed efficiency, and phenotypically through volatile fatty acids (Williams et al., 2019) and rumen $\mathrm{pH}$ (Moate et al., 2020). If the required reference population size becomes available through proxy traits or international collaboration, it is likely that more records will be required to achieve the same level of accuracy, proportional to the genetic correlation, as often genetic correlations between countries (van den Berg et al., 2016; Haile-Mariam et al., 2020), measurement techniques and with proxy traits are less than one (Ismael et al., 2015).

There are several ways to calculate the prediction accuracy of larger reference populations. The assumptions behind these methods vary, which can result in considerable discrepancies between accuracies obtained (Brard and Ricard, 2015). Therefore, we also tested an approach applied by van den Berg et al. (2019), which uses the accuracy of cross-validation in a small data set to estimate $\theta$ and apply the estimated $\theta$ to a larger reference population size. This method indicated that approximately 15,000 animals may be needed to

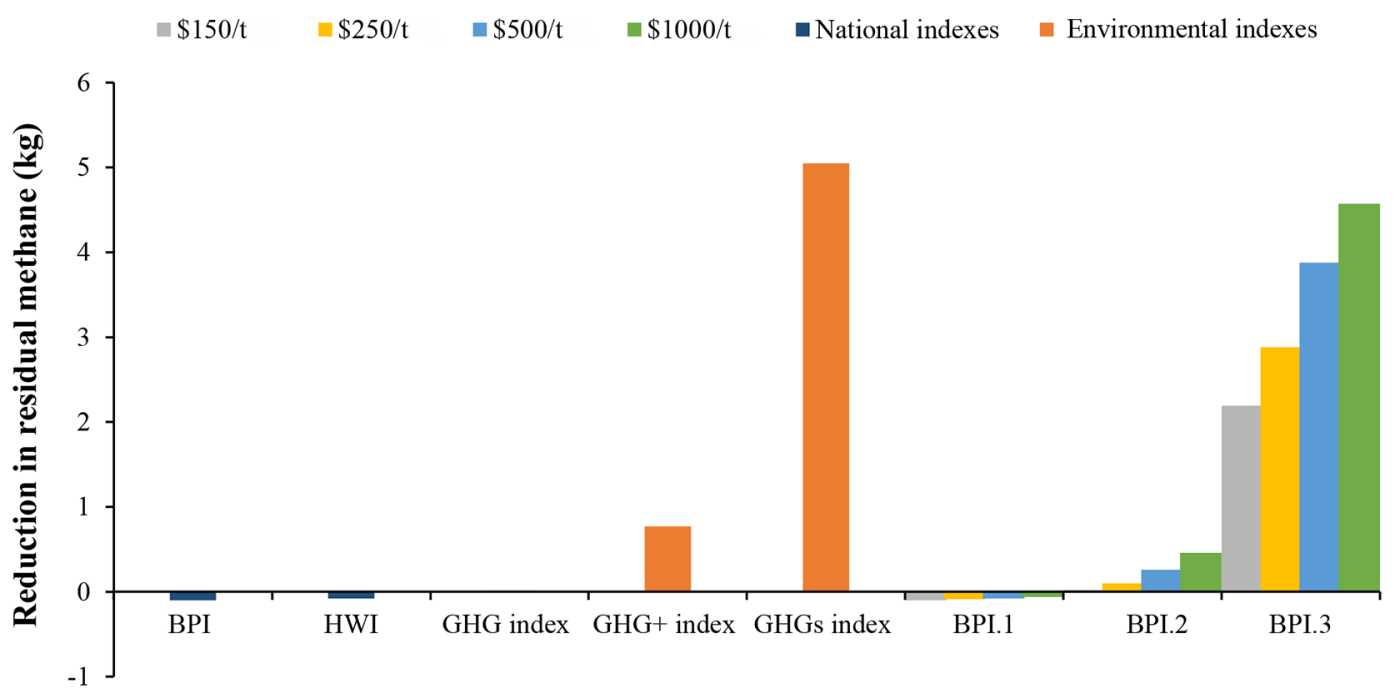

Figure 4. Environmental response per cow per year based on selection on each index for a 1-SD improvement in the Balanced Performance Index (BPI) or approximately $10 \mathrm{yr}$ of selection, equivalent to AUD $\$ 84.06$, as BPI units are $\$ A U D$ per cow per year, at carbon prices of $\$ 150 / t$ (gray), \$250/t (yellow), $\$ 500 / \mathrm{t}$ (light blue), and $\$ 1,000 / \mathrm{t}$ (green). Environmental response is presented for the residual methane trait (either currently available or simulated) for when each index is implemented. HWI = Health Weighted Index. The GHG index $_{\text {was }}$ developed as described by Richardson et al. (2021c) and updated to include a gross emissions value for residual methane (GHG ${ }^{+}{ }_{\text {index }}$ ) as well as a simulated residual methane trait with higher accuracy $\left(\mathrm{GHG}^{\mathrm{S}}\right.$ index $)$. BPI.1, BPI.2, and BPI.3 describe scenarios where the $\mathrm{GHG}_{\text {index }}$, $\mathrm{GHG}^{+}{ }_{\text {index }}$, and $\mathrm{GHG}^{\mathrm{S}}{ }_{\text {index }}$ have been included in the BPI, respectively. 


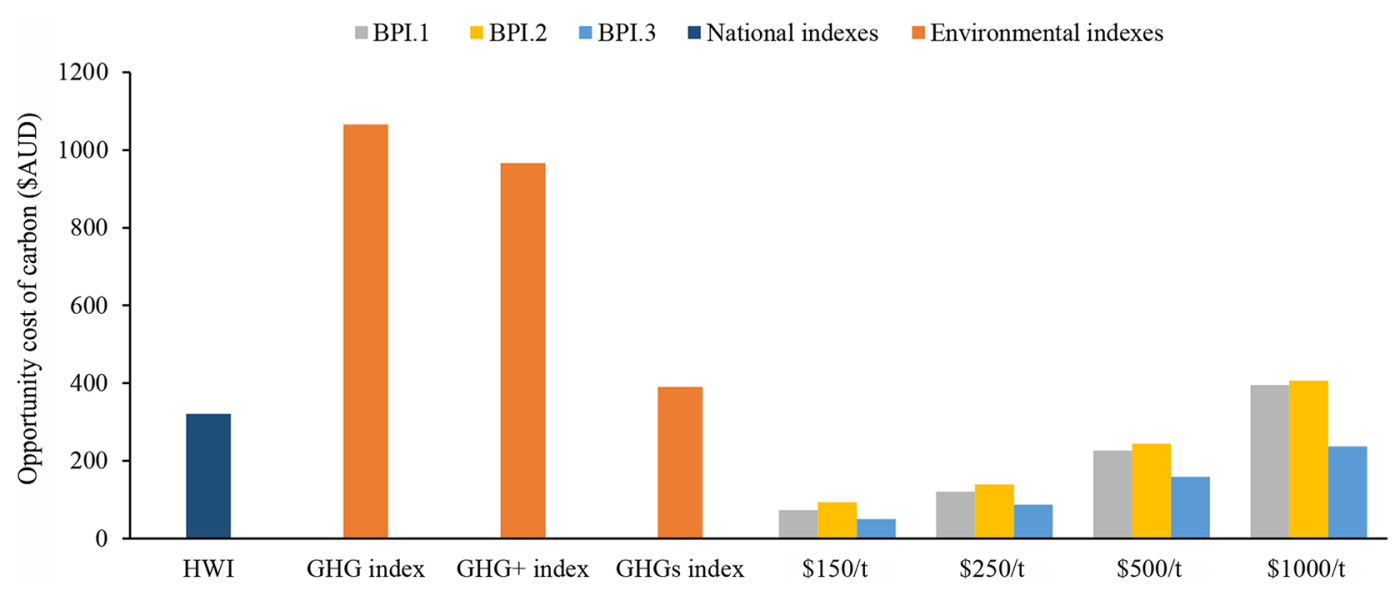

Figure 5. Opportunity costs of carbon emissions gains achieved through breeding for each index with emphasis on emissions were derived by taking the ratio of the reduction in Balanced Performance Index (BPI) units achieved in AUD $\$$ per cow per year relative to the reduction in $\mathrm{CO}_{2}$ equivalents $\left(\mathrm{CO}_{2}\right.$-eq) per cow per year when compared with the same index without any emphasis on emissions. In all scenarios, the opportunity cost of carbon to farmers was substantially lower than the applied carbon prices of $\$ 150 / \mathrm{t}, \$ 250 / \mathrm{t}, \$ 500 / \mathrm{t}$, and $\$ 1,000 / \mathrm{t}$. HWI $=$ Health Weighted Index. The $\mathrm{GHG}_{\text {index }}$ was developed as described by Richardson et al. (2021c) and updated to include a gross emissions value for residual methane $\left(\mathrm{GHG}^{+}{ }_{\text {index }}\right)$ as well as a simulated residual methane trait with higher accuracy $\left(\mathrm{GHG}^{\mathrm{S}}\right.$ index $)$. BPI.1, BPI.2, and BPI.3 describe scenarios where the $\mathrm{GHG}_{\text {index }}, \mathrm{GHG}^{+}{ }_{\text {index }}$, and $\mathrm{GHG}^{\mathrm{S}}$ index have been included in the BPI, respectively.

achieve the desired accuracy of 0.5 . Hence, a risk exists that that targeted reference population sizes may not deliver expected genomic prediction accuracies in the future, due to the uncertainty in predicting accuracies that may be obtained with future reference populations.

\section{Sacrifice in BPI}

Overall, we observed that using the proposed indices (BPI.1., BPI.2, and BPI.3) would lead to a sizable reduction in GHG emissions without much compromise in genetic gain for BPI. This reduction in rate of genetic gain in BPI is driven primarily by a general decrease in selection responses for production and conformation traits, whereas greater gains are realized in feed effi- ciency, fertility, health, and survival traits, as well as a large predicted responses in methane traits, especially when they are included in the subindex. The level of sacrifice in BPI progress is dependent on the economic value placed on carbon. In the scenario where carbon is given the economic value of $\mathrm{AUD} \$ 250 / \mathrm{t}$, only 2 to $10 \%$ of BPI gains are to achieve 35 to $117 \mathrm{~kg}$ of $\mathrm{CO}_{2}$-eq reduction, depending on the GHG subindex included in BPI. However, given an economic value of $\operatorname{AUD} \$ 1,000 / \mathrm{t}$ of carbon, progress in BPI is still made, but at $70 \%$ of the progress compared with selection on BPI directly over a 10-yr period (Figure 2). The progress in BPI observed through selection on BPI.1, BPI.2, and BPI.3 at extreme values of carbon shows the contribution of survival, health, and efficiency traits within the BPI,

Table 6. Expected reduction in gross greenhouse gas (GHG) emissions and emissions intensity after 10, 30, and $50 \mathrm{yr}$ of genetic selection on BPI. $3^{1}$ at a carbon price of AUD $\$ 250 / \mathrm{t}$ or opportunity cost to farmers of AUD $\$ 87.22 / \mathrm{t}$

\begin{tabular}{lcccc}
\hline $\begin{array}{l}\text { Period of genetic } \\
\text { selection, yr }{ }^{2,3}\end{array}$ & $\begin{array}{c}\text { Gross } \\
\text { emissions }\end{array}$ & $\begin{array}{c}\text { Reduction in } \\
\text { gross emissions, \% }\end{array}$ & $\begin{array}{c}\text { Emissions } \\
\text { intensity }\end{array}$ & $\begin{array}{c}\text { Reduction in emissions } \\
\text { intensity, \% }\end{array}$ \\
\hline 10 & 5.85 & 2.78 & 11.68 & $7.84 \%$ \\
30 & 5.52 & 8.23 & 9.98 & $21.25 \%$ \\
50 & 5.20 & 13.68 & 8.57 & $32.34 \%$ \\
\hline
\end{tabular}

${ }^{1}$ BPI.3 describes a scenario in which the $\mathrm{GHG}^{\mathrm{S}}$ index has been included in the Balanced Performance Index (BPI). The $\mathrm{GHG}_{\text {index }}$ was developed as described by Richardson et al. (2021c) and updated to include a gross emissions value for residual methane $\left(\mathrm{GHG}^{+}{ }_{\text {index }}\right)$ or a simulated residual methane trait with higher accuracy $\left(\mathrm{GHG}_{\text {index }}^{\mathrm{S}}\right)$.

${ }^{2}$ Assuming a per-cow current emissions output of 4,297.86 $\mathrm{kg}$ of $\mathrm{CO}_{2}$ equivalents $\left(\mathrm{CO}_{2}\right.$-eq), an average production level of $339.29 \mathrm{~kg}$ of protein equivalents (protein-eq), a national herd size of 1.4 million cows, and current trait genetic trends (Richardson et al., 2021c).

${ }^{3}$ Protein-eq were estimated as described in Richardson et al. (2021c).

${ }^{4}$ Where gross emission is measured in million tonnes of $\mathrm{CO}_{2}$-eq and emission intensity is measured in $\mathrm{kg}$ of $\mathrm{CO}_{2}$-eq/ $\mathrm{kg}$ of protein-eq. 
as, in these scenarios, production and conformation traits receive negative weights. Interestingly, on average 18.06 units of BPI gain occur over $10 \mathrm{yr}$ through selecting only on the GHG subindexes, which is $21 \%$ of the 10-yr gain in BPI if emissions were ignored.

\section{Comparing to HWI}

When considering options to reduce emissions at the national level, the influence of current national indexes was also considered. In all scenarios, the reduction achieved by implementing a GHG subindex was greater than selection on BPI alone. However, at lower carbon prices, selection using the HWI resulted in a larger reduction in emissions compared with the indexes that did not include a reliable residual methane trait. In fact, the magnitude of the reduction in emissions from selection on HWI is comparable to BPI.1 at a carbon price of AUD $\$ 500 /$ t. However, by selecting on BPI.1, we reduce emissions by an additional $\sim 4 \mathrm{~kg}$ of $\mathrm{CO}_{2}$-eq per cow per BPI SD while also achieving an additional 1.5 points of progress in BPI, compared with HWI. Therefore, the actual cost of carbon for farmers is only AUD $\$ 226.92 / \mathrm{t}$ when selecting for BPI.1, whereas the cost of carbon for farmers is much higher at AUD $\$ 320.77 / \mathrm{t}$ when selecting for HWI. This is due to the difference in relative emphasis for each trait within the respective indexes. Relative emphasis of traits within BPI.1 is more evenly distributed than HWI, with more weight on survival $(16 \%)$, fertility (16\%), and efficiency traits (11\%). The HWI is dominated by fertility (29\% relative emphasis), which leads to an expected comparable reduction in emissions as BPI.1. The BPI.1 at a carbon price of AUD $\$ 500 / t$ still maintains a reasonably high focus on production traits, with a total relative emphasis of $30 \%$, compared with HWI where the relative emphasis drops to $23 \%$. This comparison highlights the differences in the indexes that have similar reductions in emissions. The BPI.1 may be more appealing to farmers, as it still maintains a strong focus on economics, resulting in a similar emissions reduction with more emphasis on traits of high economic value. However, when the simulated residual methane trait is included, all of the current national indexes are substantially below the reduction achieved in emissions by selecting for BPI.3 at any economic value.

\section{Applied and Realized Economic Values of Environmental Traits}

The reductions in methane are expressed in $\mathrm{CO}_{2}$-eq to allow for a more meaningful representation of the enteric methane reduction dealt with in this paper- meaningful insofar as it allows for fair comparison to be made between sectors and gases. Additionally, it prepares the industry for the possible introduction of a carbon market, at which point a live economic value would need to be placed on methane.

Currently, there is no economic incentive for farmers to select for methane reduction. Unlike other traits included in the national breeding objective, no price signal currently exists to influence selection choices. However, it is expected that in the near future a carbon market will be implemented in Australia and could be introduced in agriculture sectors globally.

The price per tonne of carbon varies greatly by country and carbon market design. In Canada, this value is set to be approximately AUD $\$ 180$ (Government of Canada, 2021) in 2030, and in the United States and the EU the carbon price is currently set as AUD $\$ 68$ and AUD\$88/t, respectively (Stern and Stiglitz, 2021). These values are significantly lower than some of the economic values of carbon tested in the current study. The difference between the global economic values of carbon and the ones tested in this study reflects that (1) the carbon price is expected to increase substantially as national carbon markets continue to develop (Stern and Stiglitz, 2021); (2) some additional weight may be given to GHG subindexes to coincide with farmers' desires and achieve a level of emissions reduction deemed acceptable to maintain the industry's social license to operate (Martin-Collado et al., 2015); and (3) the realized cost to farmers is far lower than the weight placed on carbon due to simultaneous response in economically valuable traits.

The reduction in emissions achieved by including any of the GHG subindexes in the BPI is largely dependent on the economic value placed on carbon and the resulting percent emphasis the GHG subindex receives in the BPI. As the economic value of GHG increases, a point is reached where the national index would be selecting against protein, milk, and fat, as shown in the scenario where the carbon price is $\operatorname{AUD} \$ 1,000 / t$ (i.e., the most valuable trait economically is methane). However, at a carbon price of $\$ 1,000 / t$, the realized opportunity cost to farmers of including a GHG subindex in the BPI is substantially less than the carbon price (Figure 5). For example, at $\$ 1,000 / \mathrm{t}$ carbon in BPI.1, the reduction in economic gain is $\$ 16.44$ (or $20 \%$ when GHG is not included in BPI). However, the benefit of this is an additional reduction of $41.61 \mathrm{~kg}$ of $\mathrm{CO}_{2}$-eq, resulting in a realized cost of carbon to producers of only $\$ 395.09 / \mathrm{t}$ $\left(\frac{-\$ 16.44}{-41.61 \mathrm{~kg} \text { of } \mathrm{CO}_{2}-\mathrm{eq}} \times 1,000 \mathrm{~kg} / \mathrm{t}\right)$. This is also the case at a carbon price of $\$ 150 / t$, where the realized cost of carbon is $\$ 73.24 / \mathrm{t}$ when selecting on BPI.1, and be- 
comes even lower when selection is based on BPI.3 $(\$ 50.38 / \mathrm{t})$. When including environmental traits within an index, if a relatively low percentage of economic gain or index progression is sacrificed, then approximately 40 to $50 \%$ of the maximum possible reductions in emissions may be achieved. This principle is a major benefit of including a methane trait within the national index, as opposed to independent selection, as more progress is made by including all traits of environmental interest simultaneously, rather than selecting for the traits separately. This concurrent selection of EBV that have a correlated favorable response in emissions (BPI.1) in addition to direct selection on a residual methane trait (BPI.2 and BPI.3) allows a high level of methane reduction to be achieved with a realized cost to farmers that is far lower than the price of carbon.

\section{Comparing Breeding Objectives for Gross Emissions and Emissions Intensity}

Previous studies have indicated 3 main opportunities to reduce emissions: (1) selection for a direct methane trait, (2) changes in herd structure, especially reducing replacements and therefore total emissions, and (3) increased production as means of diluting emissions per liter (Wall et al., 2010). Targeting options 1 and 2 is the focus of this paper, as they contribute to reducing gross emissions, which is consistent with the current national GHG reduction goals of Australia. The third option targets a reduction in EI through a dilution effect of generating more product per unit of emissions output.

This research focuses on reducing gross emissions, as this is the most likely breeding objective for the Australian dairy industry in the future. However, we do recognize that other breeding objectives that target a reduction in EI may be more favorable for some systems, especially in the agricultural sector. Although the current study only applied gross coefficients, methods exist that calculate coefficients based on intensity (Zhang et al., 2019) and have been estimated for the Australian industry (Richardson et al. 2021c).

The resulting difference when applying these intensity weights in the index is that increases in production traits are not penalized due to the dilution effect. An emission intensity reduction strategy is most effective in reducing a national industry inventory where production levels remain constant, as gross methane will also be reduced due to having fewer animals to produce the same level of output. However, reducing EI is not necessarily environmentally friendly if animal numbers remain the same or increase. In practice, at a policy level it is very hard to constrain the national level of output. The gross emissions approach used here is likely to be much more amenable to reducing Australia's national inventory, but the global benefit of this would be diminished if loss of future increases in milk production from the Australian dairy industry result in higher future milk production from countries with a much less favorable EI than Australia (Ledgard et al., 2020).

\section{Other Applications for GHG Subindex Values}

The implementation of each of the GHG subindexes will result in a reduction in emissions and increase in farm efficiency. This is done not only by selecting for a direct methane trait but also by quantifying the effects that other traits have on the level of methane produced. This is consistent with other studies, which have identified improvement in longevity as a major factor to reduce on-farm emissions when production or farm size are stationary (Lahart et al., 2021). The implementation of these indexes may help the industry reach state or national targets for emission reductions and international goals set for 2030 to maintain the $1.5^{\circ} \mathrm{C}$ warming rate.

The GHG indexes may also be used to quantify, on a large scale, individual animal GHG from a management perspective. As a management tool, the GHG subindex may be used to rank farms or individual cows and identify those animals or farms that are the lowest GHG emitters (Zhang et al., 2021). In terms of quantifying emissions inventories for individual farms or animals, base breed averages can be applied to translate genetic improvements back to the phenotypic scale as a way for farmers to document carbon release from cows. Finally, implementation demonstrates to the consumer that the dairy industry is dedicated to maintaining its industry social license to operate by reducing its emissions and maintaining its sustainable structure.

\section{CONCLUSIONS}

The results presented in the current study indicate that, in the short term, a GHG subindex tool that farmers can use for industry application will be effective in reducing emissions while maintaining profits. Although the current estimated residual methane EBV is not accurate enough for implementation, GV coefficients may be applied to traits currently included in the national breeding objective to reduce emissions. Subsequently, when accurate residual methane EBV become available in the near future, a substantial increase in the reduction of emissions may be achieved, as shown through the simulated residual methane trait. The GHG subindexes in this study demonstrate the environmental benefit, with minimal economic sacrifice, of including a direct methane trait, as well as placing additional emphasis on traits known to affect emissions, in the 
national selection index. By implementing a GHG subindex in the national breeding program, we can achieve up to a $7.9 \%$ decrease in residual methane and 9 times the reduction in gross emissions in $10 \mathrm{yr}$ compared with the current breeding program, with little to no cost to farmers. By 2050, selection based on the BPI.3 at carbon price of AUD $\$ 250 / \mathrm{t}$, or opportunity cost to farmers of $\$ 87.22$, will reduce gross emissions by $8.23 \%$ and EI by $21.25 \%$.

\section{ACKNOWLEDGMENTS}

We thank DairyBio (Bundoora, Victoria, Australia), jointly funded by Dairy Australia (Melbourne, Australia), the Gardiner Foundation (Melbourne), and Agriculture Victoria (Melbourne) for funding C. M. Richardson's $\mathrm{PhD}$ project. We also thank DataGene (Bundoora) for the provision of estimated breeding values. The authors have not stated any conflicts of interest.

\section{REFERENCES}

Appuhamy, J. A., J. France, and E. Kebreab. 2016. Models for predicting enteric methane emissions from dairy cows in North America, Europe, and Australia and New Zealand. Glob. Change Biol. 22:3039-3056. https://doi.org/10.1111/gcb.13339.

Axford, M., B. Santos, K. Stachowicz, C. Quinton, J. E. Pryce, and P. Amer. 2021. Impact of a multiple-test strategy on breeding index development for the Australian dairy industry. Anim. Prod. Sci. 61:1940-1950.

Basarab, J. A., K. A. Beauchemin, V. S. Baron, K. H. Ominski, L. L. Guan, S. P. Miller, and J. J. Crowley. 2013. Reducing GHG emissions through genetic improvement for feed efficiency: Effects on economically important traits and enteric methane production. Animal 7:303-315. https://doi.org/10.1017/S1751731113000888.

Boichard, D., and M. Brochard. 2012. New phenotypes for new breeding goals in dairy cattle. Animal 6:544-550. https://doi.org/10 $1017 /$ S1751731112000018

Bolormaa, S., I. M. MacLeod, M. Khansefid, L. Marett, B. Wales, G. J. Nieuwhof, C. F. Baes, F. S. Schenkel, M. E. Goddard, and J. E. Pryce. 2021. Next generation feed saved Australian breeding values evaluated in Holstein dairy cattle. Proc. Assoc. Advmt. Anim. Breed. Genet. 24:377-381.

Brard, S., and A. Ricard. 2015. Is the use of formulae a reliable way to predict the accuracy of genomic selection? J. Anim. Breed. Genet. 132:207-217.

Breider, I. S., E. Wall, and P. C. Garnsworthy. 2019. Heritability of methane production and genetic correlations with milk yield and body weight in Holstein-Friesian dairy cows. J. Dairy Sci. 102:7277-7281. https://doi.org/10.3168/jds.2018-15909.

Byrne, T. J., B. F. S. Santos, P. R. Amer, D. Martin-Collado, J. E. Pryce, and M. Axford. 2016. New breeding objectives and selection indices for the Australian dairy industry. J. Dairy Sci. 99:81468167. https://doi.org/10.3168/jds.2015-10747.

de Haas, Y., M. Pszczola, H. Soyeurt, E. Wall, and J. Lassen. 2017. Invited review: Phenotypes to genetically reduce greenhouse gas emissions in dairying. J. Dairy Sci. 100:855-870. https://doi.org/ $10.3168 /$ jds.2016-11246.

de Haas, Y., R. F. Veerkamp, G. de Jong, and M. N. Aldridge. 2021. Selective breeding as a mitigation tool for methane emissions from dairy cattle. Animal 15:100294. https://doi.org/10.1016/j.animal .2021 .100294 .
Deighton, M. H., S. R. O. Williams, M. C. Hannah, R. J. Eckard, T. M. Boland, W. J. Wales, and P. J. Moate. 2014. A modified sulphur hexafluoride tracer technique enables accurate determination of enteric methane emissions from ruminants. Anim. Feed Sci. Technol. 197:47-63. https://doi.org/10.1016/j.anifeedsci.2014 .08.003.

Gerber, P. J., A. N. Hristov, B. Henderson, H. Makkar, J. Oh, C. Lee, R. Meinen, F. Montes, T. Ott, J. Firkins, A. Rotz, C. Dell, A. T. Adesogan, W. Z. Yang, J. M. Tricarico, E. Kebreab, G. Waghorn, J. Dijkstra, and S. Oosting. 2013. Technical options for the mitigation of direct methane and nitrous oxide emissions from livestock: A review. Animal 7:220-234. https://doi.org/10.1017/ S1751731113000876.

Goddard, M. E., B. J. Hayes, and T. H. Meuwissen. 2011. Using the genomic relationship matrix to predict the accuracy of genomic selection. J. Anim. Breed. Genet. 128:409-421. https://doi.org/10 $.1111 / \mathrm{j} .1439-0388.2011 .00964 . x$.

González-Recio, O., M. P. Coffey, and J. E. Pryce. 2014. On the value of the phenotypes in the genomic era. J. Dairy Sci. 97:7905-7915. https://doi.org/10.3168/jds.2014-8125.

González-Recio, O., J. López-Paredes, L. Ouatahar, N. Charfeddine, E. Ugarte, R. Alenda, and J. A. Jiménez-Montero. 2020. Mitigation of greenhouse gases in dairy cattle via genetic selection: 2 Incorporating methane emissions into the breeding goal. J. Dairy Sci. 103:7210-7221. https://doi.org/10.3168/jds.2019-17598.

Government of Canada. 2021. Carbon pollution pricing system across Canada. Accessed Jul. 27, 2021. https://www.canada.ca/ en/environment-climate-change/services/climate-change/pricing -pollution-how-it-will-work.html.

Haile-Mariam, M., I. M. MacLeod, S. Bolormaa, C. Schrooten, E. O'Connor, G. de Jong, H. D. Daetwyler, and J. E. Pryce. 2020. Value of sharing cow reference population between countries on reliability of genomic prediction for milk yield traits. J. Dairy Sci. 103:1711-1728.

Ismael, A., E. Strandberg, M. Kargo, A. Fogh, and P. Løvendahl. 2015. Estrus traits derived from activity measurements are heritable and closely related to the time from calving to first insemination. J. Dairy Sci. 98:3470-3477. https://doi.org/10.3168/jds.2014-8940.

Lahart, B., L. Shalloo, J. Herron, D. O'Brien, R. Fitzgerald, T. M. Boland, and F. Buckley. 2021. Greenhouse gas emissions and nitrogen efficiency of dairy cows of divergent economic breeding index under seasonal pasture-based management. J. Dairy Sci. 104:80398049. https://doi.org/10.3168/jds.2020-19618.

Ledgard, S. F., S. J. Falconer, R. Abercrombie, G. Philip, and J. P. Hill. 2020. Temporal, spatial, and management variability in the carbon footprint of New Zealand milk. J. Dairy Sci. 103:1031-1046. Manzanilla-Pech, C. I. V., P. Løvendahl, D. Mansan Gordo, G. F. Difford, J. E. Pryce, F. Schenkel, S. Wegmann, F. Miglior, T. C. Chud, P. J. Moate, S. R. O. Williams, C. M. Richardson, P. Stothard, and J. Lassen. 2021. Breeding for low methane emitting and feed efficient Holstein cows: An international response. J. Dairy Sci. 104:8983-9001. https://doi.org/10.3168/jds.2020-19889.

Martin-Collado, D., T. Byrne, P. Amer, B. Santos, M. Axford, and J. Pryce. 2015. Analyzing the heterogeneity of farmers' preferences for improvements in dairy cow traits using farmer typologies. J. Dairy Sci. 98:4148-4161. https://doi.org/10.3168/jds.2014-9194.

Moate, P. J., M. H. Deighton, J. Jacobs, B. E. Ribaux, G. L. Morris, M. C. Hannah, D. Mapleson, M. S. Islam, W. J. Wales, and S. R. O. Williams. 2020. Influence of proportion of wheat in a pasturebased diet on milk yield, methane emissions, methane yield, and ruminal protozoa of dairy cows. J. Dairy Sci. 103:2373-2386. https: //doi.org/10.3168/jds.2019-17514.

Newton, J. E., R. Nettle, and J. E. Pryce. 2020. Farming smarter with big data: Insights from the case of Australia's national dairy herd milk recording scheme. Agric. Syst. 181:102811. https://doi.org/10 .1016/j.agsy.2020.102811.

Paris Agreement. 2016. The Paris Agreement. Accessed Dec. 11, 2020. https://unfccc.int/process-and-meetings/the-paris-agreement/the -paris-agreement.

Pryce, J. E., O. Gonzalez-Recio, G. Nieuwhof, W. J. Wales, M. P. Coffey, B. J. Hayes, and M. E. Goddard. 2015. Hot topic: Definition 
and implementation of a breeding value for feed efficiency in dairy cows. J. Dairy Sci. 98:7340-7350.

Pryce, J. E., and M. Haile-Mariam. 2020. Symposium review: Genomic selection for reducing environmental impact and adapting to climate change. J. Dairy Sci. 103:5366-5375. https://doi.org/10 $.3168 /$ jds.2019-17732.

R Core Team. 2021. R: A Language and Environment for Statistical Computing. R Foundation for Statistical Computing. https://www .R-project.org/.

Richardson, C. M., P. R. Amer, F. Hely, I. van den Berg, and J. E. Pryce. 2021a. Estimating methane coefficients to predict the environmental impact of traits in the Australian dairy breeding program. J. Dairy Sci. 104:10979-10990. https://doi.org/10.3168/ jds.2021-20348.

Richardson, C. M., T. T. T. Nguyen, M. Abdelsayed, P. J. Moate, S. R. O. Williams, T. C. S. Chud, F. S. Schenkel, M. E. Goddard, I. van den Berg, B. G. Cocks, L. C. Marett, W. J. Wales, and J. E. Pryce. 2021b. Genetic parameters for methane emission traits in Australian dairy cows. J. Dairy Sci. 104:539-549. https://doi.org/ $10.3168 / j d s .2020-18565$.

Richardson, C. M., B. Sunduimijid, P. R. Amer, I. van den Berg, and J. E. Pryce. 2021c. A method for implementing methane breeding values in Australian dairy cattle. Anim. Prod. Sci. 61:1781-1787. https://doi.org/10.1071/AN21055.

Scott, B. A., M. Haile-Mariam, I. M. MacLeod, and J. E. Pryce. 2021. Does selecting for the a $2 \beta$-casein allele increase inbreeding? Proc. Assoc. Advmt. Anim. Breed. Genet. 24:361-364.

Stern, N., and J. E. Stiglitz. 2021.The social cost of carbon, risk, distribution, market failures: An alternative approach. Working paper 28472. Accessed Jan. 14, 2022. National Bureau of Economic Research. https://www.nber.org/papers/w28472.

UNFCCC (United Nations Framework Convention on Climate Change). 2018. National Inventory Submissions 2018. Accessed Nov. 15, 2019. https://unfccc.int/process-and-meetings/transparency-and -reporting/reporting-and-review-under-the-convention/greenhouse -gas-inventories-annex-i-parties/national-inventory-submissions -2018 .

van den Berg, I., D. Boichard, B. Guldbrandtsen, and M. S. Lund. 2016. Using sequence variants in linkage disequilibrium with causative mutations to improve across-breed prediction in dairy cattle: A simulation study. G3 (Bethesda) 6:2553-2561.

van den Berg, I., T. H. E. Meuwissen, I. M. MacLeod, and M. E. Goddard. 2019. Predicting the effect of reference population on the accuracy of within, across, and multibreed genomic prediction. J. Dairy Sci. 102:3155-3174.

Vanlierde, A., H. Soyeurt, N. Gengler, F. G. Colinet, E. Froidmont, M. Kreuzer, F. Grandl, M. Bell, P. Lund, D. W. Olijhoek, and M. Eugène. 2018. Development of an equation for estimating methane emissions of dairy cows from milk Fourier transform mid-infrared spectra by using reference data obtained exclusively from respiration chambers. J. Dairy Sci. 101:7618-7624.

VanRaden, P. M. 2008. Efficient methods to compute genomic predictions. J. Dairy Sci. 91:4414-4423. https://doi.org/10.3168/jds .2007-0980.

Wall, E., C. Ludemann, H. Jones, E. Audsley, D. Moran, T. Roughsedge, and P. R. Amer. 2010. The potential for reducing greenhouse gas emissions for sheep and cattle in the UK using genetic selection. Final Report to DEFRA. DEFRA.

Williams, S. R. O.. M. C. Hannah. J. L. Jacobs, W. J. Wales, and P. J. Moate. 2019. Volatile fatty acids in ruminal fluid can be used to predict methane yield of dairy cows. Animals (Basel) 9:1006. https://doi.org/10.3390/ani9121006.

World Bank. 2021. Carbon Pricing Dashboard. Accessed Aug. 2, 2021. https:// carbonpricingdashboard.worldbank.org/what-carbon -pricing.

Zhang, Q., G. Difford, G. Sahana, P. Løvendahl, J. Lassen, M. S. Lund, B. Guldbrandtsen, and L. Janss. 2020. Bayesian modeling reveals host genetics associated with rumen microbiota jointly influence methane emission in dairy cows. ISME J. 14:2019-2033. https://doi.org/10.1038/s41396-020-0663-x.

Zhang, X., P. R. Amer, G. M. Jenkins, J. A. Sise, B. Santos, and C. Quinton. 2019. Predictions of effects of dairy selection indexes on methane emissions. J. Dairy Sci. 102:11153-11168. https://doi .org/10.3168/jds.2019-16943.

Zhang, X., P. R. Amer, K. Stachowicz, C. Quinton, and J. Crowley. 2021. Herd-level versus animal-level variation in methane emission prediction in grazing dairy cattle. Animal 15:100325. https://doi .org/10.1016/j.animal.2021.100325.

Zimin, A. V., A. L. Delcher, L. Florea, D. R. Kelley, M. C. Schatz, D. Puiu, F. Hanrahan, G. Pertea, C. P. Van Tassell, T. S. Sonstegard, G. Marçais, M. Roberts, P. Subramanian, J. A. Yorke, and S. L. Salzberg. 2009. A whole-genome assembly of the domestic cow, Bos taurus. Genome Biol. 10:R42. https://doi.org/10.1186/ gb-2009-10-4-r42.

\section{ORCIDS}

C. M. Richardson @ https://orcid.org/0000-0003-4286-4969

P. R. Amer (ㄴ) https://orcid.org/0000-0002-6428-7165

C. Quinton (ㄴ) https://orcid.org/0000-0001-6824-4624

F. S. Hely @ https://orcid.org/0000-0002-6134-7142

I. van den Berg (๑) https://orcid.org/0000-0002-9292-8636

J. E. Pryce $\odot$ https://orcid.org/0000-0002-1397-1282 